\title{
Nastrój rodziców dzieci z mózgowym porażeniem dziecięcym
}

\begin{abstract}
Wędzińska Magdalena, Mood of parents with children suffering from cerebral palsy [Nastrój rodziców dzieci z mózgowym porażeniem dziecięcym]. Interdyscyplinarne Konteksty Pedagogiki Specjalnej, nr 1, Poznań 2013. Pp. 13-36. Adam Mickiewicz University Press. ISBN 978-83-232-2539-3.

This paper is devoted to the issue of mood of parents of children suffering from cerebral palsy in relation to the characteristics of child (mental retardation and form of the disease) and sociodemographic variables (age, gender, abode and level of education) of parents. The results shows that examined mothers feel higher activity, vigor than fathers. The results show also that the mood of the parents is partly depend on their gender, level of education and form of child's disease. Paper presents also theoretical issues associated with mood of parents and the results of previous studies on that problem.
\end{abstract}

KEY WORDS: mood, parents, children suffering from cerebral palsy

\section{Wprowadzenie}

Każda rodzina może doświadczać sytuacji trudnej w związku ze zmianami i wydarzeniami, które mają w niej miejsce. Jednakże niepełnosprawność i choroba członka rodziny jest problemem szczególnie obciążającym. Siła przeżywanego kryzysu zależy od wielkości zmian, które rodzice muszą wprowadzić w definicję swego wymarzonego dziecka. Pojawienie się niepełnosprawnego dziecka w ro- 
dzinie angażuje bardzo mocno rodziców w opiekę nad nim. Często potrzeba opieki nad dzieckiem jest tak duża, że przekracza możliwości rodziców, co prowadzi do kryzysu organizacji roli. Muszą oni wybierać pomiędzy poświęcaniem swojej energii i czasu dziecku a pełnieniem ról społecznych, domowych, realizacją własnych planów życiowych, wypełnianiem zobowiązań wobec innych członków rodziny. Może to być przyczyną konfliktów w rodzinie oraz licznych problemów emocjonalnych ${ }^{1}$. Niepełnosprawność dziecka i opieka nad nim niewątpliwie znajdują odbicie w nastroju jego rodziców. Celem tego artykułu jest zaprezentowanie nastroju, jakiego doświadczają rodzice dzieci z mózgowym porażeniem dziecięcym (MPDz) przy uwzględnieniu czynników związanych z chorobą i czynników społeczno-demograficznych.

\section{Nastrój}

Nastrój w potocznym rozumieniu uważany jest za coś ulotnego, zmiennego, a zarazem „wszechobecnego". Jak stwierdza Mario Fedeli, nastrój jest aspektem temperamentu, jedynie częściowo podatnym na wpływ czynników zewnętrznych, wydarzeń życiowych. Jest głównie związany ze stopniem wrażliwości i kierunkiem odpowiedzi emocjonalnej danej osoby ${ }^{2}$. Keith Oatley i Jennifer Jenkins uważają, iż nastrój odnosi się do stanu emocjonalnego, który trwa zwykle przez pewien okres (godziny, dnie, tygodnie), czasem jako tło o niskiej intensywności. Może być niejasne, kiedy nastrój się zaczyna i kiedy kończy. Nastroje są często bezprzedmiotowe, nieukierunkowane na konkretny przedmiot ${ }^{3}$. James Russell definiuje nastrój jako przedłużający się afekt rdzenny bez obiektu. Oznacza to, że trudno wskazać,

${ }^{1} \mathrm{~J}$. Bąbka, Wspomaganie rodzin wychowujących dziecko niepetnosprawne w placówkach realizujacych edukacje integracyjna, [w:] A. Siedlaczek-Szwed, I. Wagner (red.), Rodzinne i pozarodzinne środowiska wychowawcze: szkice historyczno-pedagogiczne, WSP, Częstochowa 2002, s. 137-146.

2 M. Fedeli, Temperamenty, charaktery, osobowość. Profil medyczny i psychologiczny, Wyd. WAM, Kraków 2003, s. 181.

${ }^{3}$ K. Oatley, J. Jenkins, Zrozumieć emocje, Wyd. Nauk. PWN, Warszawa 2003, s. 125. 
co jest przyczyną lub adresatem danego nastroju. Obiektem nastroju może być osoba, rzecz lub zdarzenie (czy to realne, czy wyobrażone, umiejscowione $\mathrm{w}$ teraźniejszości, w przeszłości lub w przyszłości). Emocje wiążą się z obiektami, nastrój zaś nie spełnia tego kryterium. Pozostawanie w danym nastroju może wiązać się z określoną przyczyną, jednakże nie jest ona bezpośrednia, a najczęściej trudna do określenia. Bycie w określonym nastroju nie wiąże się ze skonkretyzowanym wydarzeniem poprzedzającym zaistnienie nastroju ${ }^{4}$. Zdaniem Paula Ekmana i Richarda Davidsona nastrój jest pojęciem pokrewnym emocjom, natomiast głównym kryterium rozróżnienia tych stanów jest ich czas trwania. W przypadku emocji jest on rzędu kilku minut, natomiast nastrój może trwać wiele godzin. Badacze ci zwracają uwagę na jeszcze jedną różnicę pomiędzy nastrojem a emocjami. Dotyczy ona ukierunkowania tych zjawisk. Emocje ukierunkowują zachowania, jest to jedna $\mathrm{z}$ ich funkcji. Nastrój natomiast wpływa raczej na procesy poznawcze niż na zachowania. Nastrój pozytywny jest związany z większą elastycznością funkcjonowania poznawczego, czego efektem może być wzrost twórczości, spostrzeganie związków pomiędzy różnymi informacjami ${ }^{5}$. David Watson i Lee Clark zakładają, iż człowiek zawsze jest w jakimś nastroju. Określają to mianem strumienia doznań afektywnych i wyróżniają dwie klasy afektu: pozytywny i negatywny. Pierwszy z nich rozumiany jest jako stopień radości i entuzjazmu, afekt negatywny zaś to stopień podenerwowania oraz zestresowania. Te dwa afekty nie są i nie powinny być traktowane jako przeciwległe krańce kontinuum. Jedynie w przypadku bardzo silnych afektów wysoki poziom jednego z nich może wywoływać niski poziom drugiego ${ }^{6}$.

${ }^{4}$ E. Goryńska, Umiejscowienie nastroju wśród zjawisk afektywnych, [w:] E. Goryńska, M. Ledzińska, M. Zajenkowski (red.), Nastrój: modele, geneza, funkcje, Wyd. UW, Warszawa 2011, s. 11-27.

${ }^{5}$ P. Ekman, R. Davidson, Co wpływa na subiektywne doświadczanie emocji, [w:] P. Ekman, R. Davidson (red.), Natura emocji. Podstawowe zagadnienia, GWP, Gdańsk 1998, s. 341-343.

${ }^{6}$ D. Watson, L. Clark, Emocje, nastroje, cechy i temperament: rozważania pojęciowe i wyniki badań, [w:] P. Ekman, R. Davidson (red.), Natura emocji. Podstawowe zagadnienia, GWP, Gdańsk 1998, s. 83-86. 


\section{Mózgowe porażenie dziecięce - obraz medyczny}

Mózgowe porażenie dziecięce (MPDz) nie jest jednostką chorobową, ale zespołem wielu objawów powstających na skutek uszkodzenia ośrodkowego układu nerwowego, zwłaszcza neuronów ruchowych w okresie ich rozwoju i dojrzewania. Mózgowe porażenie dziecięce jest zaburzeniem bardzo niejednolitym, zarówno klinicznie, i jak i etiologicznie. Poza skutkami fizycznymi wywołuje ono wiele następstw psychospołecznych ${ }^{7}$.

Pojęciem mózgowego porażenia dziecięcego określa się różnorodne, niepostępujące zaburzenia czynności ruchowych, będące następstwem uszkodzeń mózgu dziecka w okresie ciąży, porodu lub w pierwszych 2-3 latach po urodzeniu, to znaczy przed osiągnięciem pewnego stopnia dojrzałości mózgu ${ }^{8}$. Powstałe zaburzenie nie nasila się $\mathrm{z}$ upływem lat, lecz wraz $\mathrm{z}$ rozwojem fizycznym dziecka mogą się nasilać objawy kliniczne. Różnorodność objawów klinicznych MPDz jest przyczyną wielu rodzajów jego klasyfikacji. Magdalena Dubis ze współpracowniczkami przywołują klasyfikację topograficzną autorstwa Rossa i Soboloffa (1953). Podział topograficzny mózgowego porażenia dziecięcego jest następujący:

- monoplegia - porażenie jednej ręki lub jednej nogi,

- hemiplegia - dotyczy obu kończyn po tej samej stronie ciała,

- triplegia - porażenie trzech kończyn, silnie zaznaczone w kończynach dolnych,

- diplegia - obustronny symetryczny niedowład,

- paraplegia - porażenie tylko kończyn dolnych,

- quadriplegia - porażenie wszystkich kończyn, lecz nieregularne, niesymetryczne ${ }^{9}$.

${ }^{7}$ K.J. Zabłocki, Mózgowe porażenie dziecięce w teorii i terapii, Wyd. Akademickie Żak, Warszawa 1998, s. 9-10.

8 B. Arusztowicz, W. Bąkowski, Dziecko kalekie jakiego nie znamy, WSiP, Warszawa 1989, s. 92.

${ }^{9}$ M. Dubis, A. Pietruszewska, J. Demczyszak, Rehabilitacja metoda NDT-Bobath dzieci z mózgowym porażeniem dziecięcym, [w:] S. Jastrzęba, A. Pozowski, M. Paproc- 
Przyczyny mózgowego porażenia dziecięcego są bardzo różne. Najczęściej wymienia się trzy grupy czynników mających wpływ na jego powstanie. Pierwszą z nich stanowią czynniki oddziaływujące w życiu płodowym, np.: urazy brzucha matki, niedotlenienie, zakażenie płodu, promieniowanie radioaktywne, leki, palenie tytoniu, picie alkoholu podczas ciąży. Drugą grupę stanowią czynniki okołoporodowe, do których zalicza się uraz okołoporodowy, niedotlenienie oraz wcześniactwo. Ostatnią grupę stanowią czynniki działające po narodzinach dziecka, np.: urazy mózgu, niedotlenienie po urodzeniu, zapalenie opon mózgowych po urodzeniu oraz znacznie nasilona żółtaczka noworodka. Irena Obuchowska podaje, że 30\% czynników uszkadzających działa w okresie płodowym, 30\% powoduje niedotlenienia i urazy okołoporodowe, 10\% to przyczyny natury genetycznej, natomiast pozostałe $30 \%$ stanowią przyczyny o nieznanym charakterze ${ }^{10}$.

\section{Przeżycia emocjonalne rodziców dzieci z mózgowym porażeniem dziecięcym}

Zdaniem Andrzeja Twardowskiego, rodzice dzieci niepełnosprawnych przechodzą przez pewne etapy adaptacji do niepełnosprawności własnego dziecka. Pierwszym z nich jest okres szoku, często nazywany okresem wstrząsu emocjonalnego. Następuje on bezpośrednio po tym, gdy rodzice dowiadują się o niepełnosprawności dziecka. Równowaga psychiczna rodziców ulega wtedy zachwianiu. W przeżyciach dominują: żal, rozpacz, poczucie krzywdy i beznadziejność. Dla większości rodziców czas ten jest pasmem cierpień i braku perspektyw na rozwiązanie sytuacji, w jakiej się znaleźli. Silne emocje przeżywane $w$ tym okresie zazwyczaj negatywnie wpływają na ustosunkowanie się rodziców do siebie i do

ka-Borowicz (red.), Rehabilitacja interdyscyplinarna, Wyd. Akademii Medycznej im. Piastów Śląskich we Wrocławiu, Wrocław 2009, s. 69-71.

${ }^{10}$ K.J. Zabłocki, dz. cyt., s. 12-13. 
dziecka. Rodzicom na tym etapie zazwyczaj brakuje wiedzy na temat tego, jak należy postępować z dzieckiem, a ich zachowania wobec niego są przepełnione lękiem lub poczuciem winy. Po okresie szoku ma miejsce okres kryzysu emocjonalnego, nazywany często okresem rozpaczy lub depresji. Rodzice nie mogą się pogodzić z faktem, że mają niepełnosprawne dziecko. Przeżywane wówczas przez nich emocje nadal są negatywne, ale już nie tak burzliwe, jak w poprzednim okresie. Sytuacja nadal jest spostrzegana przez nich jako beznadziejna i bez wyjścia. Często u rodziców może pojawiać się poczucie winy wynikające z przekonania, iż to oni ponoszą odpowiedzialność za niepełnosprawność dziecka. Pesymistycznie oceniają również przyszłość dziecka. W stosunkach z otoczeniem może pojawić się bunt i wrogość ${ }^{11}$. W okresie tym może wystąpić także zjawisko odsuwania się ojca od rodziny. Przejawiać się ono może zarówno poprzez niezajmowanie się sprawami rodziny i dziecka, ucieczkę $\mathrm{w}$ nałogi czy pracę lub całkowite odejście od rodziny ${ }^{12}$. Ojcowie mogą cierpieć z powodu niepełnosprawności dziecka równie mocno jak matki. Co więcej, społeczny stereotyp silnego mężczyzny może utrudniać im odreagowanie tych silnych emocji. Kobiety mogą znaleźć ulgę w codziennych zabiegach wokół dziecka, co daje im poczucie, że robią dla niego coś ważnego i potrzebnego. Codzienne czynności pielęgnacyjne dziecka sprzyjają powstawaniu bliskiej i intymnej więzi między matką a dzieckiem, natomiast ojcowie, zaangażowani w mniejszym niż matka stopniu w opiekę nad dzieckiem, siłą rzeczy mają mniej możliwości do nawiązywania więzi z dzieckiem ${ }^{13}$.

Sytuację emocjonalną ojców dzieci niepełnosprawnych, upośledzonych umysłowo, badała, wykorzystując techniki projekcyjne, między innymi Bożena Sidor. Stwierdziła u nich głębokie reakcje

${ }^{11}$ A. Twardowski, Sytuacja rodzin dzieci niepetnosprawnych, [w:] I. Obuchowska (red.), Dziecko niepetnosprawne w rodzinie, WSiP, Warszawa 1991, s. 18-52.

${ }_{12}$ M. Sekułowicz, Matki dzieci z mózgowym porażeniem dziecięcym wobec problemów życiowych, Wyd. Uniw. Wrocławskiego, Wrocław 2000, s. 24-35.

${ }^{13}$ M. Paruchomik, Rodzice dzieci z mózgowym porażeniem dziecięcym wobec sytuacji trudnych, Towarzystwo Naukowe KUL, Lublin, 2007, s. 56-71. 
depresyjne maskowane obojętnością. Pod pozornym nieprzejmowaniem się własną sytuacją kryła się rozpacz połączona z poczuciem beznadziejności i bezradności ${ }^{14}$. Należy również mieć na uwadze, że matka obciążona obowiązkami pielęgnacyjnymi i przytłoczona negatywnymi emocjami może prezentować wobec ojca postawę wrogości, pretensji, a tym samym przyczyniać się do odsunięcia go od rodziny ${ }^{15}$.

Po okresie kryzysu emocjonalnego ma miejsce okres pozornego przystosowania się. Jego dominującą cechą jest podejmowanie przez rodziców nieracjonalnych prób radzenia sobie z sytuacją niepełnosprawności dziecka, która silnie narusza ich równowagę emocjonalną. Frustracja oczekiwań związanych ze zdrowieniem, kierunkiem rozwoju dziecka powoduje, że rodzice nie zawsze potrafią zaakceptować dziecko takim, jakim ono jest w rzeczywistości. Często koncentrują się zbytnio na ograniczeniach dziecka i w związku z tym nadmiernie je chronią, stają się wobec niego permisywni lub je odtrącają ${ }^{16}$. Rodzice niemogący pogodzić się z tym faktem, stosują różnorodne mechanizmy obronne, wytwarzając sobie obraz dziecka zwykle niemający pokrycia w rzeczywistości. Zwykle występującym mechanizmem obronnym jest negowanie niepełnosprawności dziecka i dążenie do obalenia postawionej diagnozy poprzez zaprzeczanie, bagatelizowanie jej lub poszukiwanie nowej. Innym mechanizmem jest nieuzasadniona wiara w możliwości wyleczenia dziecka. Rodzice podejmują żmudne i kosztowne wysiłki polegające na poszukiwaniu środków mogących uzdrowić ich dziecko. Kolejnym mechanizmem obronnym, mogącym pojawić się u rodziców, jest poszukiwanie winnych niepełnosprawności dziecka. Oskarżenia padają pod adresem lekarzy, kiedy to rodzice są przekonani, że

${ }^{14}$ B. Sidor, Trudności przeżywane przez rodzinę dziecka z niepetnosprawnościa umystowa, [w:] D. Kornas-Biela (red.), Rodzina: źródto życia i szkoła miłości, Towarzystwo Naukowe KUL, Lublin 2001, s. 393-405.

${ }^{15} \mathrm{~B}$. Arusztowicz, Akceptacja dziecka $z$ dysfunkcja narzadu ruchu przez samego siebie i przez najbliższe otoczenie, „Szkoła Specjalna” 1995, nr 5, s. 131-140.

${ }^{16}$ M. Karwowska, Wspieranie rodziny dziecka niepetnosprawnego umystowo, Wyd. Impuls, Kraków 2003, s. 29-30. 
błędy zostały popełnione czy to podczas prowadzenia ciąży, czy podczas porodu, mimo iż obiektywnie nie ma powodów, by tak przypuszczać. Winą bywają obarczane również siły nadprzyrodzone (los, Bóg). Niepełnosprawność dziecka bywa traktowana jako kara za własne przewinienia. Winą rodzice mogą obarczać siebie nawzajem, na przykład zarzucając sobie zaburzenia genetyczne czy niedostateczne opiekowanie się dzieckiem. Okres pozornego przystosowania się może trwać bardzo długo. Kiedy rodzice wyczerpią wszelkie środki i możliwości, mogą wówczas dojść do przekonania, że nie mogą dla dziecka nic więcej zrobić. Pogodzeni w ten sposób ze stanem rzeczy poddają się apatii, przygnębieniu i pesymizmowi. W swoich działaniach wobec dziecka ograniczają się do czynności pielęgnacyjnych. Swoje zawiedzione wobec dziecka nadzieje mogą przenosić na zdrowe dzieci, często stawiając im wygórowane wymagania. Może również dojść do takiego zorganizowania rodziny, w której dziecko niepełnosprawne jest poza jej nawiasem ${ }^{17}$.

Ostatnią fazą adaptowania się jest okres konstruktywnego przystosowania się. Na tym etapie rodzice poszukują konstruktywnego rozwiązania problemu - czy, a jeśli tak, to w jaki sposób można pomóc dziecku. Zastanawiają się nad kwestiami dotyczącymi realnych przyczyn niepełnosprawności, jaki wywiera ona wpływ na rozwój dziecka i na funkcjonowanie całej rodziny. Rodzice wypracowują sposób postępowania $\mathrm{z}$ dzieckiem, zastanawiają się nad jego przyszłością. Zaczynają stosować różne zabiegi wychowawcze i rehabilitacyjne wobec dziecka. Opieka nad niepełnosprawnym dzieckiem oparta jest na współpracy rodziców. W przeżyciach emocjonalnych zaczynają dominować uczucia pozytywne, zarówno kontakt $\mathrm{z}$ dzieckiem, jak i czynności pielęgnacyjne na jego rzecz zaczynają przynosić im satysfakcję. Rodzice dostrzegają postępy dziecka, które są dla nich źródłem radości ${ }^{18}$. Akceptacja dziecka niechybnie wpływa na jego percepcję. Rodzice akceptujący dziecko spostrzegają je bardziej obiektywnie, widząc nie tylko ograniczenia

\footnotetext{
17 A. Twardowski, Sytuacja rodzin..., dz. cyt.

18 Tamże.
} 
i niedostatki, ale i możliwości. Obraz dziecka funkcjonujący w ich świadomości jest bardziej adekwatny, realistyczny i optymistyczny. Co więcej, akceptacja dziecka wpływa również na sposób komunikowania się z nim. Rodzice akceptujący swe niepełnosprawne dziecko nie są tylko i wyłącznie nastawieni na przekazywanie mu informacji, lecz preferują jej dwustronny charakter - są nastawieni na odbiór informacji od dziecka ${ }^{19}$.

\section{Sytuacja socjodemograficzna rodziców dzieci z MPDz}

$\mathrm{Na}$ funkcjonowanie i odczucie rodziców dzieci z mózgowym porażeniem dziecięcym i rodziców dzieci niepełnosprawnych w ogóle - niewątpliwie - rzutuje ich ogólna sytuacja społeczna. Dotychczasowe badania dotyczące rodziców dzieci z MPDz wskazują, iż płeć, wykształcenie oraz miejsce zamieszkania mogą różnicować nie tylko sytuację społeczną, ale i odczuwany przez rodziców nastrój.

\section{Płeć rodzica}

Susan Goldberg (1990) prowadziła badania dotyczące związku pomiędzy wielkością stresu rodzicielskiego a płcią rodzica dziecka z MPDz. Z jej badań wynika, iż matki dzieci niepełnosprawnych doświadczają większego stresu i trudności adaptacyjnych w związku z zaburzeniami rozwoju dziecka niż ojcowie. Ojcowie wykazują mniej symptomów życia w stresie, mają wyższą samoocenę oraz bardziej wewnętrzne umiejscowienie poczucia kontroli niż matki, mimo iż otrzymują mniej wsparcia społecznego niż one. Matki były bardziej depresyjne, miały niższe poczucie własnej wartości jako

19 A. Twardowski, Problemy akceptacji dziecka niepetnosprawnego przez rodzinę, [w:] R. Ossowski (red.), Sytuacja życiowa dziecka niepetnosprawnego w rodzinie, Wyd. WSP, Bydgoszcz 1991, s. 39-48. 
rodzica. Problemy z wychowywaniem niepełnosprawnego dziecka wpływały nie tylko na jakość związku z partnerem, ale i na zdrowie badanych matek. Ojcowie natomiast zgłaszali problemy z przywiązaniem do dziecka, zwłaszcza gdy było ono płci męskiej. Doświadczali również większego stresu wynikającego $\mathrm{z}$ temperamentu dziecka ${ }^{20}$.

\section{Wiek rodzica}

$\mathrm{Na}$ funkcjonowanie w sytuacji niepełnosprawności dziecka wpływ może mieć również wiek, w jakim są jego rodzice. Osoby młodsze wielokrotnie doświadczają rozczarowania $\mathrm{z}$ powodu niepełnosprawności dziecka. Co więcej, niepełnosprawność często rodzi obawy o funkcjonowanie w przyszłości czy o zdrowie przyszłego potomstwa. Natomiast rodzice, którzy w późniejszym wieku decydują się na rodzicielstwo lub którzy mieli problem z posiadaniem dzieci, znacznie łatwiej adaptują się do sytuacji niepełnosprawności. Jednakże rodzice wraz z dorastaniem dzieci niepokoją się o ich przyszłość, martwią się, kto ich dzieciom zapewni opiekę, kiedy ich już zabraknie ${ }^{21}$.

\section{Poziom wykształcenia rodzica}

Związek wykształcenia rodziców dzieci niepełnosprawnych $\mathrm{z}$ ich funkcjonowaniem badał między innymi Barry Trute wraz ze współpracownikami (2008). Wnioski płynące z jego badań wskazywały, iż wyższe wykształcenie sprzyjało stosowaniu aktywnych sposobów radzenia sobie ze stresem i obiektywnej ocenie włas-

${ }^{20}$ S. Goldberg, P. Morris, R. Fowler, H. Levinson, Chronic illness in infancy and parenting stress. A comparison of Three Groups of Parents, "Journal of Pediatric Psychology" 1990, nr 15(7), s. 61-84.

${ }^{21}$ E. Pisula, Psychologiczne problemy rodziców dzieci z zaburzeniami rozwoju, Wyd. UW, Warszawa, 1998, s. 60-62. 
nej sytuacji życiowej. Rodzice z wyższym poziomem wykształcenia wykazywali się również większą otwartością na potrzeby dziecka ${ }^{22}$.

\section{Miejsce zamieszkania rodziny}

Podstawową różnicą pomiędzy funkcjonowaniem rodziny z dzieckiem niepełnosprawnym $\mathrm{w}$ środowisku wiejskim i miejskim jest charakter stosunków społecznych utrzymywanych ze środowiskiem. „Społeczność wiejska charakteryzuje się przede wszystkim: wzajemną znajomością jej członków, bezpośrednim charakterem kontaktów międzyludzkich, dużą jednorodnością poglądów, zainteresowań i wartości oraz wspólnym charakterem wykonywanej pracy. Niewielka liczebność tej społeczności, jej duża zwartość i częste kontakty pomiędzy jej członkami powodują, że rodzina mająca niepełnosprawne dziecko nie jest odrzucana i izolowana. Również dziecko niepełnosprawne ma szanse na uzyskanie akceptacji ze strony rówieśników i dorosłych. W mieście natomiast (zwłaszcza w dużych aglomeracjach) naturalne kręgi społeczne ulegają znacznemu rozluźnieniu. Zanikają tradycyjne więzi sąsiedzkie i zainteresowanie drugim człowiekiem. Stosunek społeczny do rodziny z dzieckiem niepełnosprawnym jest zazwyczaj obojętny lub niechętny. Wieś, w porównaniu z miastem, nie stwarza również tylu barier, na przykład natury architektonicznej czy komunikacyjnej, dziecku niepełnosprawnemu ruchowo. Tym samym dziecko zamieszkujące wieś może łatwiej i szerzej uczestniczyć w życiu swojej społeczności. Jednakże rodziny dzieci niepełnosprawnych mieszkające na wsi borykają się z utrudnieniami na przykład w postaci dostępu do placówek rehabilitacyjnych, leczniczych i oświatowych, które znajdują się ośrodkach miejskich, wielokrotnie bardzo odległych od miejsca zamieszkania rodziny.

22 B. Trute, C. Worthington, D. Hiebert-Murphy, Grandmother Support for parents of children with disabilities: Gender differences in parenting stress, „Families, Systems \& Health" 2008, nr 26(2), s. 135-146. 
Mieszkańcy wsi, często ze względu na niższy poziom wykształcenia, nie widzą potrzeby poddawania dziecka okresowym badaniom lekarskim lub konsultacjom psychologicznym czy pedagogicznym²3.

\section{Cel badań}

Celem badań było sprawdzenie, czy odczuwany przez rodziców nastrój związany jest z cechami dziecka (takimi jak postać jego choroby oraz współwystępowanie z mózgowym porażeniem dziecięcym upośledzenia umysłowego, bez różnicowanie stopnia upośledzenia) oraz z ich sytuacją społeczną wyrażoną w: płci, wieku, miejscu zamieszkania i poziomie wykształcenia.

\section{Problem i hipotezy badawcze}

$\mathrm{Na}$ podstawie analizy teoretycznej sformułowano następujące pytania badawcze:

1. Czy cechy dziecka (postać choroby, występowanie lub brak upośledzenia umysłowego) mają związek $\mathrm{z}$ odczuwanym przez rodziców nastrojem?

2. Czy istnieje związek pomiędzy nastrojem odczuwanym przez rodziców dzieci z MPDz a ich sytuacją socjodemograficzną (płeć, wiek, miejsce zamieszkania oraz poziom wykształcenia)?

$\mathrm{W}$ odpowiedzi na powyższe problemy badawcze postawiono następujące hipotezy:

1. Istnieje związek pomiędzy nastrojem rodziców a cechami dziecka z MPDz wyrażonymi w postaci jego choroby oraz współwystępowaniu wraz z mózgowym porażeniem dziecięcym upośledzenia umysłowego:

- im cięższa postać choroby dziecka, tym bardziej zaznacza się u rodziców przewaga nastroju negatywnego nad pozytywnym,

${ }^{23}$ A. Twardowski, Sytuacja rodzin ..., dz. cyt. 
- upośledzenie umysłowe dziecka sprzyja dominacji nastroju negatywnego nad pozytywnym u rodziców.

2. Istnieje związek pomiędzy nastrojem a zmiennymi socjodemograficznymi cechującymi rodziców:

- $\mathrm{u}$ matek występuje dominacja nastroju negatywnego w stosunku do nastroju odczuwanego przez ojców,

- nastrój odczuwany przez rodziców obniża się wraz z ich wiekiem,

- nastrój rodziców dzieci z MPDz rośnie wraz z ich poziomem wykształcenia,

- rodzice dzieci z MPDz mieszkający na wsi odczuwają w większym stopniu nastrój pozytywny niż rodzice dzieci z MPDz mieszkający w mieście.

\section{Metoda badawcza}

\section{Narzędzia pomiaru}

Do oceny nastroju odczuwanego przez badanych rodziców użyto Kwestionariusza Samopoczucia (Profile of Mood States - POMS) Douglasa McNaira, Maurice'a Lorra i Leo Dropplemana (1992). Pytania dotyczące cech dziecka (postać choroby, występowanie lub brak upośledzenia umysłowego) oraz sytuacji socjodemograficznej rodziców (wiek, poziom wykształcenia, miejsce zamieszkania) znalazły się w ankiecie osobowej.

Kwestionariusz POMS może być przeznaczony do badania młodzieży i dorosłych. Składa się z 65 przymiotników określających różne stany emocjonalne i nastroje, które mogą być doświadczane przez człowieka. Badani określali je poprzez ustosunkowanie się, $\mathrm{w}$ jakim stopniu $\mathrm{w}$ ciągu ostatniego tygodnia doznawali wymienionych odczuć (na skali 5-stopniowej, gdzie 0 oznacza - zdecydowanie nie wystąpił dany stan, a 4 - zdecydowanie odczuwano dany stan). Instrukcja sformułowana w ten sposób miała na celu uzyskanie uogólnionej oceny nastroju i zmniejszenie ewentualnego wpływu pojedynczych wydarzeń na ten samoopis. 
Wyniki POMS ujmowane są w postaci sześciu skal:

1. Niepokój-napięcie (9 itemów), skala odnosząca się do napięcia mięśniowego, niekiedy niewidocznego w bezpośredniej obserwacji, oznacza uogólniony stan dyskomfortu.

2. Depresja-przygnębienie (15 itemów), odnosi się do nastroju smutku z uogólnionym poczuciem nieadekwatności, poczuciem winy, poczuciem mniejszej wartości od innych oraz emocjonalnej izolacji od innych.

3. Złość-wrogość (15 itemów), oznacza gniew i wrogość wobec innych, złośliwość, zgorzkniałość, drażliwość oraz buntowniczość.

4. Wigor-aktywność (8 itemów), oznacza stan dużej energii, pokładów witalnych, chęci do działania, nastrój pogodny, negatywnie koreluje z pozostałymi pięcioma skalami.

5. Zmęczenie-znużenie (7 itemów), oznacza poczucie bezwładności, znużenia i niskiego zasobu energii oraz powolność i wyczerpanie.

6. Zakłopotanie-zmieszanie (7 itemów), oznacza trudność w koncentracji uwagi, zapominanie, poczucie braku skuteczności w działaniu oraz stan zdezorganizowania.

Pięć skal opisuje emocje negatywne, a jedynie skala wigor-aktywność odnosi się do pozytywnych emocji. Autorzy testu oraz autorzy polskiej jego wersji oceniają poziom jego trafności i rzetelności jako satysfakcjonujący. Współczynniki zgodności wewnętrznej dla analizowanych skal wahały się od 0,84 do 0,9524.

\section{Osoby badane}

Badania przeprowadzono na grupie rodziców przyprowadzających swoje dzieci na rehabilitację ruchową. Kryterium doboru było wychowywanie dziecka dotkniętego mózgowym porażeniem dziecięcym. Udział w badaniu był dobrowolny i anonimowy.

${ }^{24}$ B. Dudek, J. Koniarek, Adaptacja testu D.M. McNoira, M. Lorra, L.F. Droppelmana: Profile of Mood States (POMS), „Przegląd Psychologiczny” 1987, nr 30, s. 753-761. 
W badaniu udział wzięły 73 osoby: 41 kobiet oraz 32 mężczyzn. Średnia wieku w grupie kobiet wynosiła 31 lat (najmłodsza badana miała 24 lata, najstarsza 40 lat), w grupie mężczyzn zaś średnia wieku wyniosła 33 lata (najmłodszy mężczyzna miał 22 lata, najstarszy 45). Wśród badanych znalazło się 26 par małżeńskich i 6 par pozostających w związku partnerskim oraz 9 matek samotnie wychowujących dzieci.

Najwięcej badanych matek miało wykształcenie średnie (46,34\%), natomiast $\mathrm{w}$ grupie badanych ojców dominowało wykształcenie zawodowe (37,5\%). Najmniejszy odsetek wśród badanych matek i ojców stanowiły osoby z wykształceniem podstawowym. Badani rodzice w większości zamieszkiwali wsie (matki 41,47\%, ojcowie $43,75 \%$ ). Najmniejszy odsetek rodziców zamieszkiwał w mniejszych ośrodkach miejskich.

Najwięcej przebadano rodziców dzieci z paraplegią $(41,46 \%$ ogółu badanych), najmniej zaś z hemiplegią, diplegią i quadriplegią. Upośledzenie umysłowe występowało u 5 dzieci, co stanowi 12,2\% ogółu badanych.

Tabela 1. Statystyki opisowe i wyniki testu różnic $t$-Studenta dla prób niezależnych nastroju rodziców

\begin{tabular}{|l|l|c|r|c|c|c|}
\hline \multicolumn{2}{|c|}{ Wymiar nastroju } & Średnia & \multicolumn{1}{|c|}{$s$} & Ważnych & $t$ & $p$ \\
\hline \multirow{2}{*}{ Niepokój, napięcie } & $\mathrm{M}$ & 16,951 & 7,807 & 41 & & \\
\cline { 2 - 8 } & $\mathrm{O}$ & 16,625 & 7,024 & 32 & 0,185 & 0,854 \\
\hline \multirow{2}{*}{ Depresja, przygnębienie } & $\mathrm{M}$ & 26,707 & 13,452 & 41 & & \\
\cline { 2 - 8 } & $\mathrm{O}$ & 28,219 & 12,228 & 32 & $-0,495$ & 0,622 \\
\hline \multirow{2}{*}{ Złość, wrogość } & $\mathrm{M}$ & 20,804 & 10,226 & 41 & & \\
\cline { 2 - 8 } & $\mathrm{O}$ & 23,594 & 9,741 & 32 & $-1,180$ & 0,242 \\
\hline \multirow{2}{*}{ Aktywność, wigor } & $\mathrm{M}$ & $\mathbf{1 6 , 2 2 0}$ & $\mathbf{6 , 2 4 5}$ & 41 & & \\
\cline { 2 - 8 } & $\mathrm{O}$ & $\mathbf{1 3 , 6 2 5}$ & $\mathbf{6 , 8 0 0}$ & $\mathbf{3 2}$ & $\mathbf{1 , 6 6 9}$ & $\mathbf{0 , 0 4 9}$ \\
\hline \multirow{2}{*}{ Zmęczenie, znużenie } & $\mathrm{M}$ & 15,463 & 6,157 & 41 & & \\
\cline { 2 - 7 } & $\mathrm{O}$ & 15,500 & 6,735 & 32 & $-0,024$ & 0,980 \\
\hline \multirow{2}{*}{ Zakłopotanie, zmieszanie } & $\mathrm{M}$ & 14,073 & 6,125 & 41 & & \\
\cline { 2 - 7 } & $\mathrm{O}$ & 13,063 & 4,866 & 32 & 0,764 & 0,448 \\
\hline
\end{tabular}

$S$ - odchylenie standardowe, $t$ - wynik testu różnic, $p$ - próg istotności 
Obliczeń dokonano za pomocą komputerowego programu statystycznego Statistica 10.0. W tabeli 1 przedstawiono statystyki opisowe dotyczące nastroju badanych rodziców oraz istotność różnic uzyskanych pomiędzy obu grupami.

Badane matki uzyskiwały wyższe średnie wyniki niż ojcowie w zakresie skal: niepokoju, napięcia; zakłopotania, zmieszania oraz aktywności, wigoru. Jednakże jedynie różnica w skali aktywności, wigoru jest istotna statystycznie.

Na podstawie powyższych wyników można stwierdzić, iż hipoteza druga potwierdziła się częściowo. Rodzice dzieci z mózgowym porażaniem dziecięcym różnią się w zakresie doświadczanego nastroju - matki są bardziej aktywne i pełne wigoru.

\section{Związek pomiędzy nastrojem a cechami dziecka}

W celu ustalenia zależności pomiędzy nastrojem rodziców a cechami dziecka z MPDz, wyrażonymi w postaci jego choroby oraz $\mathrm{w}$ występowaniu z MPDz upośledzenia umysłowego, zastosowano współczynnik korelacji rho-Spearmana.

Tabela 2. Związek rho-Spearmana pomiędzy cechami dzieci z MPDz a nastrojem ich ojców

\begin{tabular}{|l|c|r|r|c|}
\hline \multicolumn{1}{|c|}{ Pary zmiennych } & $\begin{array}{c}N- \\
\text { ważnych }\end{array}$ & $\begin{array}{c}R- \\
\text { Spearman }\end{array}$ & $t(N-2)$ & $p$ \\
\hline Niepokój, napięcie i postać choroby dziecka & 32 & 0,233 & 1,310 & 0,200 \\
\hline Niepokój, napięcie i upośledzenie & 32 & 0,052 & 0,287 & 0,776 \\
\hline $\begin{array}{l}\text { Depresja, przygnębienie i postać choroby } \\
\text { dziecka }\end{array}$ & 32 & 0,267 & 1,519 & 0,139 \\
\hline Depresja, przygnębienie i upośledzenie & 32 & 0,134 & 0,739 & 0,466 \\
\hline Złość, wrogość i postać choroby dziecka & $\mathbf{3 2}$ & $\mathbf{0 , 3 7 7}$ & $\mathbf{2 , 2 3 1}$ & $\mathbf{0 , 0 3 3}$ \\
\hline Złość, wrogość i upośledzenie & 32 & 0,012 & 0,064 & 0,950 \\
\hline Aktywność, wigor i postać choroby dziecka & 32 & $-0,061$ & $-0,334$ & 0,741 \\
\hline Aktywność, wigor i upośledzenie & 32 & $-0,233$ & $-1,311$ & 0,200 \\
\hline
\end{tabular}


cd. tab. 2

\begin{tabular}{|l|c|r|r|c|}
\hline \multicolumn{1}{|c|}{ Pary zmiennych } & $\begin{array}{c}N- \\
\text { ważnych }\end{array}$ & $\begin{array}{c}R- \\
\text { Spearman }\end{array}$ & $t(N-2)$ & $p$ \\
\hline $\begin{array}{l}\text { Zmęczenie, znużenie i postać choroby } \\
\text { dziecka }\end{array}$ & 32 & 0,348 & 2,036 & 0,051 \\
\hline Zmęczenie, znużenie i upośledzenie & 32 & 0,216 & 1,210 & 0,236 \\
\hline $\begin{array}{l}\text { Zakłopotanie, zmieszanie i postać choroby } \\
\text { dziecka }\end{array}$ & 32 & 0,344 & 2,006 & 0,054 \\
\hline Zakłopotanie, zmieszanie i upośledzenie & 32 & 0,146 & 0,807 & 0,426 \\
\hline
\end{tabular}

Związki pomiędzy nastrojem odczuwanym przez matki a cechami dziecka wyrażonymi w postaci jego choroby oraz występowania lub braku upośledzenie umysłowego okazały się nieistotne statystycznie. Ujawnił się natomiast istotny statystycznie związek pomiędzy postacią choroby dziecka a nastrojem badanych ojców. Im cięższa postać choroby dziecka, tym większa złość i wrogość u ojców (tab. 2).

$\mathrm{U}$ badanych matek nie wystąpił istotny statystycznie związek pomiędzy nastrojem a cechami dziecka. Natomiast postać choroby dziecka koreluje dodatnio z odczuwaną przez badanych ojców złością, wrogością. Pozwala to na częściowe przyjęcie hipotezy pierwszej.

\section{Związki pomiędzy nastrojem a sytuacją socjodemograficzną rodziców}

Do oceny związku pomiędzy nastrojem odczuwanym przez badanych rodziców a ich wiekiem użyto współczynnika korelacji r-Pearsona. W badaniu ujawnił się istotny statystycznie związek pomiędzy nastrojem a wiekiem badanych ojców. Wiek ojców dodatnio koreluje $\mathrm{z}$ odczuwanym przez nich zmęczeniem, znużeniem. Jego nasilenie rośnie wraz z wiekiem badanych ojców. Wiek koreluje również ujemnie $\mathrm{z}$ aktywnością, wigorem, który maleje wraz ze starzeniem się ojców. Nie ma natomiast istotnych statystycznie związków pomiędzy nastrojem a wiekiem badanych matek (tab. 3). 
Tabela 3. Związek r-Pearsona pomiędzy wiekiem rodziców dzieci z MPDz a odczuwanym nastrojem

\begin{tabular}{|l|c|c|}
\hline \multicolumn{1}{|c|}{ Testowany związek } & Wiek matki & Wiek ojca \\
\hline \multirow{2}{*}{ Niepokój, napięcie } & 0,041 & 0,029 \\
\cline { 2 - 3 } & $p=0,798$ & $p=0,873$ \\
\hline \multirow{2}{*}{ Depresja, przygnębienie } & 0,160 & 0,226 \\
\cline { 2 - 3 } & $p=0,317$ & $p=0,215$ \\
\hline \multirow{2}{*}{ Złość, wrogość } & 0,045 & 0,146 \\
\hline \multirow{2}{*}{ Aktywność, wigor } & $p=0,782$ & $p=0,425$ \\
\hline \multirow{2}{*}{ Zmęczenie, znużenie } & $-0,268$ & $\mathbf{- 0 , 3 6 0}$ \\
\cline { 2 - 3 } & $p=0,091$ & $\boldsymbol{p}=\mathbf{0 , 0 4 3}$ \\
\hline \multirow{2}{*}{ Zakłopotanie, zmieszanie } & 0,153 & $\mathbf{0 , 3 6 1}$ \\
\cline { 2 - 3 } & $p=0,340$ & $\boldsymbol{p}=\mathbf{0 , 0 4 3}$ \\
\cline { 2 - 3 } & 0,128 & 0,212 \\
\hline
\end{tabular}

Do oceny związku pomiędzy poziomem wykształcenia i miejscem zamieszkania a nastrojem badanych rodziców użyto współczynnika rho-Spearmana. Związki pomiędzy nastrojem badanych rodziców a wymienionymi zmiennymi socjodemograficznymi przedstawiono w tabelach 4 i 5.

Tabela 4. Związek rho-Spearmana pomiędzy nastrojem matek a ich miejscem zamieszkania i wykształceniem

\begin{tabular}{|l|c|r|r|c|}
\hline \multicolumn{1}{|c|}{ Pary zmiennych } & $\begin{array}{c}N- \\
\text { ważnych }\end{array}$ & $\begin{array}{r}R- \\
\text { Spearman }\end{array}$ & $t(N-2)$ & $p$ \\
\hline Niepokój, napięcie i miejsce zamieszkania & 41 & 0,060 & 0,378 & 0,707 \\
\hline Niepokój, napięcie i wykształcenie & 41 & $-0,208$ & $-1,326$ & 0,193 \\
\hline $\begin{array}{l}\text { Depresja, przygnębienie i miejsce zamiesz- } \\
\text { kania }\end{array}$ & 41 & 0,048 & 0,300 & 0,766 \\
\hline Depresja, przygnębienie i wykształcenie & 41 & $-0,196$ & $-1,246$ & 0,220 \\
\hline Złość, wrogość i miejsce zamieszkania & 41 & 0,172 & 1,087 & 0,284 \\
\hline
\end{tabular}


cd. tab. 4

\begin{tabular}{|l|c|c|c|c|}
\hline \multicolumn{1}{|c|}{ Pary zmiennych } & $\begin{array}{c}N- \\
\text { ważnych }\end{array}$ & $\begin{array}{c}R- \\
\text { Spearman }\end{array}$ & $t(N-2)$ & $p$ \\
\hline Złość, wrogość i wykształcenie & 41 & $-0,139$ & $-0,877$ & 0,386 \\
\hline Aktywność, wigor i miejsce zamieszkania & 41 & 0,123 & 0,771 & 0,445 \\
\hline Aktywność, wigor i wykształcenie & $\mathbf{4 1}$ & $\mathbf{0 , 4 3 0}$ & $\mathbf{2 , 9 7 6}$ & $\mathbf{0 , 0 0 5}$ \\
\hline Zmęczenie, znużenie i miejsce zamieszkania & 41 & 0,073 & 0,456 & 0,651 \\
\hline Zmęczenie, znużenie i wykształcenie & 41 & $-0,258$ & $-1,666$ & 0,104 \\
\hline $\begin{array}{l}\text { Zakłopotanie, zmieszanie i miejsce zamiesz- } \\
\text { kania }\end{array}$ & 41 & 0,069 & 0,429 & 0,670 \\
\hline
\end{tabular}

Tabela 5. Związek rho-Spearmana pomiędzy nastrojem ojców a ich miejscem zamieszkania i wykształceniem

\begin{tabular}{|l|c|c|c|c|}
\hline \multicolumn{1}{|c|}{ Pary zmiennych } & $\begin{array}{c}N- \\
\text { ważnych }\end{array}$ & $\begin{array}{c}R- \\
\text { Spearman }\end{array}$ & $t(N-2)$ & $p$ \\
\hline Niepokój, napięcie i miejsce zamieszkania & 32 & 0,253 & 1,433 & 0,162 \\
\hline Niepokój, napięcie i wykształcenie & 32 & 0,093 & 0,513 & 0,612 \\
\hline $\begin{array}{l}\text { Depresja, przygnębienie i miejsce za- } \\
\text { mieszkania }\end{array}$ & 32 & 0,021 & 0,115 & 0,909 \\
\hline Depresja, przygnębienie i wykształcenie & 32 & $-0,169$ & $-0,941$ & 0,354 \\
\hline Złość, wrogość i miejsce zamieszkania & 32 & $-0,036$ & $-0,198$ & 0,844 \\
\hline Złość, wrogość i wykształcenie & 32 & $-0,071$ & $-0,392$ & 0,698 \\
\hline Aktywność, wigor i miejsce zamieszkania & 32 & $-0,042$ & $-0,230$ & 0,819 \\
\hline Aktywność, wigor i wykształcenie & 32 & 0,312 & 1,796 & 0,083 \\
\hline Zmęczenie, znużenie i miejsce zamieszkania & 32 & $-0,062$ & $-0,340$ & 0,736 \\
\hline Zmęczenie, znużenie i wykształcenie & 32 & $-\mathbf{0 , 3 6 0}$ & $\mathbf{- 2 , 1 1 4}$ & $\mathbf{0 , 0 4 3}$ \\
\hline $\begin{array}{l}\text { Zakłopotanie, zmieszanie i miejsce za- } \\
\text { mieszkania }\end{array}$ & 32 & $-0,026$ & $-0,140$ & 0,890 \\
\hline Zakłopotanie, zmieszanie i wykształcenie & 32 & $-0,202$ & $-1,130$ & $\mathbf{0 , 2 6 7}$ \\
\hline
\end{tabular}

W badaniu ujawnił się istotny statystycznie związek pomiędzy poziomem wykształcenia a nasileniem aktywności, wigoru u badanych matek. Im wyższy poziom wykształcenia mają badane, tym bardziej są aktywne. 
W badaniu ujawnił się istotny statystycznie związek pomiędzy poziomem wykształcenia badanych ojców a odczuwanym przez nich zmęczeniem, znużeniem. Im niższy poziom wykształcenia mają badani ojcowie, tym większe odczuwają zmęczenie, znużenie.

Badane matki, w porównaniu do badanych ojców, odczuwają bardziej nasiloną aktywność, wigor. Co więcej, aktywność, wigor matek rośnie wraz z ich poziomem wykształcenia. U badanych ojców natomiast im niższy poziom wykształcenia, tym mniejsza aktywność, wigor i tym większe zmęczenie, znużenie. Zmęczenie, znużenie ojców rośnie $\mathrm{z}$ ich wiekiem. U badanych rodziców nie odnotowano istotnego statystycznie związku pomiędzy odczuwanym nastrojem a miejscem zamieszkania. Pozwala to na częściowe przyjęcie hipotezy drugiej.

\section{Wnioski i dyskusja wyników}

Problem badawczy dotyczył nastroju rodziców dzieci z mózgowym porażeniem dziecięcym oraz jego związku z cechami dziecka (postać choroby oraz występowanie lub brak upośledzenia umysłowego), a także z sytuacją socjodemograficzną rodziców (wiek, miejsce zamieszkania, poziom wykształcenia).

$\mathrm{Na}$ podstawie wyników badań sformułowano następujące wnioski:

1. Związek pomiędzy nastrojem badanych matek a cechami dziecka wyrażonymi w postaci jego choroby oraz występowaniu u niego lub braku upośledzenia umysłowego nie jest istotny statystycznie. Zaznaczył się natomiast $\mathrm{w}$ badaniu istotny związek pomiędzy złością i wrogością odczuwaną przez ojców a postacią choroby dziecka. Im cięższa postać choroby dziecka, tym większa złość i wrogość odczuwane przez ojców.

Choroba dziecka nie tylko zmienia organizację życia rodziny, podział ról, ale i wyobrażenie o sobie jako o rodzicu. Ojcowie, podobnie jak matki, doświadczają silnego stresu rodzicielskiego. Szczególne problemy wiążą ze sposobem komunikowania się z dziec- 
kiem, określeniem więzi, jaka ich z nim łączy, a także troską o zapewnienie bytu materialnego rodzinie. Dodatkowo stres rodzicielski ojców potęgowany jest przez społeczno-kulturowy wzór ojcostwa ${ }^{25}$. Wszystko to sprzyjać może narastaniu u ojców nastroju złości i wrogości.

Zastanawiający brak istotnego statystycznie związku pomiędzy obiektywnymi cechami dotyczącymi dziecka a nastrojem matek tłumaczyć można stosowaniem przez matki innych strategii radzenia sobie ze stresem rodzicielskim. Ewa Pisula, badając strategie stosowane przez rodziców dzieci niepełnosprawnych, dowiodła, iż matki, w porównaniu do ojców, częściej wybierają konstruktywne strategie radzenia sobie, to jest akceptowanie nieprzewidywalności zdarzeń życiowych, koncentrację na teraźniejszości oraz docenianie małych kroków w rozwoju dziecka. Badani ojcowie częściej wybierali strategie polegające na izolowaniu się od problemów i ich zaprzeczaniu, a także uciekaniu $\mathrm{w}$ pracę zawodową lub $\mathrm{w}$ nałogi. Stosowanie przez badane matki adaptacyjnych strategii radzenia sobie pozwala na nieuzależnianie nastroju od cech dziecka ${ }^{26}$.

2. Badane matki, w porównaniu do badanych ojców, odczuwają bardziej nasiloną aktywność, wigor. Co więcej, istotny statystycznie związek ujawnił się pomiędzy poziomem wykształcenia badanych matek a odczuwaniem przez nie aktywności, wigoru - im wyższy poziom wykształcenia mają badane matki, tym większą aktywność i wigor odczuwają. Występuje również istotny statystycznie związek pomiędzy wiekiem badanych ojców a odczuwanym przez nich nastrojem. Im starsi ojcowie, tym mniejszą aktywność i wigor odczuwają, natomiast nasila się u nich odczuwanie zmęczenia, znużenia. Co więcej, im niższy poziom wykształcenia mają badani ojcowie, tym odczuwają większe zmęczenie, znużenie.

Zmienne socjodemograficzne, takie jak płeć, wiek oraz poziom wykształcenia, częściowo różnicują nastrój odczuwany przez bada-

${ }^{25}$ E. Pisula, Strategie radzenia sobie ze stresem a dobrostan psychiczny u matek dzieci o zaburzonym rozwoju, „Psychiatria Polska” 1996, nr 30, s. 221-232.

26 Tamże. 
nych rodziców. Zastanawiająca jest różnica pomiędzy badanymi matkami i ojcami w zakresie odczuwania przez nich aktywności, wigoru (nastrój pozytywny). Badane matki w stosunku do badanych ojców odczuwały bardziej nasiloną aktywność i wigor. Tłumaczyć to można podziałem ról $\mathrm{w}$ rodzinie oraz społecznym przyzwoleniem na wyrażanie emocji w zależności od płci. Krystyna Mrugalska zwraca uwagę na różnice w definiowaniu roli matki i ojca ${ }^{27}$. Ojcowie mniej angażując się w bezpośrednią opiekę nad dziećmi, często przebywając poza domem z uwagi na aktywność zawodową, mają mniejsze szanse na przepracowanie problemów związanych z dzieckiem. Ojcowie, podobnie jak matki, odczuwają stratę, frustrację, złość. Jednak mają mniej okazji, by stworzyć przeciwwagę dla tych uczuć przez bezpośredni udział w opiece nad dzieckiem, w jego pielęgnowaniu i wspomaganiu rozwoju. Mogą oni też mieć większe niż matki trudności w ekspresji tych uczuć, a także mniejsze możliwości na uzyskanie wsparcia społecznego. Matki zaś, poprzez opiekę nad dziećmi, mają szansę na przepracowanie negatywnych emocji. Co więcej, specyfika postaci choroby dziecka może je predysponować do większego zaangażowania w pielęgnację, wspomaganie rozwoju dziecka. Tym samym choroba dziecka może wymóc na jego matce większą aktywność. Świadomość bycia potrzebną dziecku, zaangażowanie $\mathrm{w}$ opiekę nad nim mogą sprawiać, iż matki te odczuwają nastrój pozytywny w postaci wigoru, aktywności.

Związek wieku badanych ojców z odczuwanym przez nich nastrojem wydaje się być oczywisty. Z upływem czasu, starzeniem się nie tylko następuje spadek sił witalnych, ale ma miejsce wzrost obaw co do przyszłości dziecka. Z badań wynika, iż u badanych ojców może wystąpić zespół wypalenia sił. Ruth Sullivan uważa, że wypalenie sił u rodziców dzieci niepełnosprawnych objawia się między innymi wyczerpaniem fizycznym, psychologicznym (uczu-

${ }^{27} \mathrm{~K}$. Mrugalska, Czy rodzice i profesjonaliści moga być sojusznikami?, [w:] H. Olechnowicz (red.), U źródet rozwoju dziecka. Wspomaganie rozwoju prawidłowego i zakłóconego, WSiP, Warszawa 1999, s. 38-50. 
cie znudzenia, złości, zniechęcenia oraz wrogości), spowodowanych przeciążeniem długotrwałą, intensywną opieką nad dzieckiem²8. Odczuwane przez badanych ojców zmęczenie, znużenie może wynikać nie tylko z sytuacji wychowywania dziecka z mózgowym porażeniem dziecięcym, ale i z czynników, które nie były uwzględnione $\mathrm{w}$ badaniu.

Związek wykształcenia rodziców dzieci niepełnosprawnych $\mathrm{z}$ ich funkcjonowaniem badał między innymi Barry Trute ${ }^{29}$. Z jego badań wynikało, iż wyższe wykształcenie sprzyjało stosowaniu aktywnych sposobów radzenia sobie ze stresem oraz obiektywnemu postrzeganiu własnej sytuacji życiowej. Może to wskazywać na większe nasilenie aktywności, wigoru u lepiej wykształconych matek i większe nasilenie zmęczenia, znużenia u gorzej wykształconych ojców. Natomiast, odczuwane przez ojców większe zmęczenie i znużenie u gorzej wykształconych ojców łączyć można z charakterem wykonywanej przez nich pracy (często pracy fizycznej), która może wymagać dużych nakładów energii.

Myślę, że czynniki uwzględnione w badaniu i ich związek z nastrojem odczuwanym przez rodziców prezentują wycinek specyfiki funkcjonowania rodziny $\mathrm{z}$ dzieckiem $\mathrm{z}$ mózgowym porażeniem dziecięcym. Zaakcentowane w badaniu czynniki różnicujące nastrój rodziców wskazują poniekąd obszary, w których rodzicom tychże dzieci należałoby udzielić wsparcia społecznego.

\section{Bibliografia}

ARUSZTOWICZ B., BĄKOWSKI W., Dziecko kalekie jakiego nie znamy, WSiP, Warszawa 1989, s. 92.

BĄBKA J., Wspomaganie rodzin wychowujacych dziecko niepetnosprawne w placówkach realizujących edukacje integracyjna, [w:] A. Siedlaczek-Szwed, I. Wagner (red.),

${ }^{28}$ M. Dąbrowska, Zjawisko wypalenia wśród matek dzieci niepetnosprawnych, Wyd. Impuls, Kraków 2005, s. 78.

${ }^{29} \mathrm{~B}$. Trute, Child and parents predictors of family adjustment in households containing young developmentally disabled children, „Family Relations” 1990, nr 39, s. 292-297. 
Rodzinne i pozarodzinne środowiska wychowawcze: szkice historyczno-pedagogiczne, Wyd. WSP, Częstochowa 2002, s. 137-146.

DUBIS M., PIETRUSZEWSKA A., DeMCZYSZAK J., Rehabilitacja metoda NDT-Bobath dzieci z mózgowym porażeniem dziecięcym, [w:] S. Jastrzęba, A. Pozowski, M. Paprocka-Borowicz (red.), Rehabilitacja interdyscyplinarna, Wyd. Akademii Medycznej im. Piastów Śląskich we Wrocławiu, Wrocław 2009, s. 69-71.

DudeK B., KoniareK J., Adaptacja testu D.M. McNoira, M. Lorra, L.F. Droppelmana: Profile of Mood States (POMS), „Przegląd Psychologiczny” 1987, nr 30, s. 753-761.

EKMAN P., DAVIDSON R., Co wptywa na subiektywne doświadczanie emocji, [w:] P. Ekman, R. Davidson (red.), Natura emocji. Podstawowe zagadnienia, GWP, Gdańsk 1998, s. 341-343.

FEDELI M., Temperamenty, charaktery, osobowość. Profil medyczny i psychologiczny, Wyd. WAM, Kraków 2003, s. 181.

GoldberG S., MORRIS P., FOWLeR R., LeVINSON H., Chronic illness in infancy and parenting stress. A comparison of Three Groups of Parents, "Journal of Pediatric Psychology" 1990, nr 15(7), s. 61-84.

GORYŃSKA E., Umiejscowienie nastroju wśród zjawisk afektywnych, [w:] E. Goryńska, M. Ledzińska, M. Zajenkowski (red.), Nastrój: modele, geneza, funkcje, Wyd. UW, Warszawa 2011, s. 11-27.

MRUGALSKA K., Czy rodzice i profesjonaliści mogą być sojusznikami?, [w:] H. Olechnowicz (red.), U źródeł rozwoju dziecka. Wspomaganie rozwoju prawidłowego i zakłóconego, WSiP, Warszawa 1999, s. 38-50.

OATLEY K., JeNKINS J., Zrozumieć emocje, Wyd. Nauk. PWN, Warszawa 2003, s. 125.

PISULA E., Psychologiczne problemy rodziców dzieci z zaburzeniami rozwoju, Wyd. UW, Warszawa 1998, s. 60-62.

PISULA E., Strategie radzenia sobie ze stresem a dobrostan psychiczny u matek dzieci o zaburzonym rozwoju, „Psychiatria Polska” 1996, nr 30, s. 221-232.

TRUTE B., Child and parents predictors of family adjustment in households containing young developmentally disabled children, „Family Relations” 1990, nr 39, s. 292-297.

TRUTE B., WORTHINGTON C., HIEBERT-MURPHY D., Grandmother Support for parents of children with disabilities: Gender differences in parenting stress, „Families, Systems \& Health" 2008, nr 26(2), s. 135-146.

TWARDOWSKI A., Sytuacja rodzin dzieci niepetnosprawnych, [w:] I. Obuchowska (red.), Dziecko niepetnosprawne w rodzinie, WSiP, Warszawa 1991, s. 18-52.

WATSON D., CLARK L., Emocje, nastroje, cechy $i$ temperament: rozważania pojęciowe i wyniki badań, [w:] P. Ekman, R. Davidson (red.), Natura emocji. Podstawowe zagadnienia, GWP, Gdańsk 1998, s. 83-86.

ZABŁOCKI K.J., Mózgowe porażenie dziecięce w teorii i terapii, Wyd. Akademickie Żak, Warszawa 1998, s. 9-10, 21-34. 